31. Bezborodov $Y u$. N. Methods of control and diagnostics of operational properties of lubricating oils by the parameters of thermooxidative stability / Yu. N. Bezborodov: Dis. ... Doct. of Tech. Sciences: 05.11 .13 / Bezborodov Yu. N. - Krasnoyarsk, 2009. - P. 402.

32. Simulation of Tribosystems and Tribometrology / F. Franek, G. Vorlaufer, W. Edelbauer, S. Bukovnik // Tribology in industry. - 2007. - Vol. 29. - № 1-2. - P.3-12.

33. Mikosyanchik O.O. / Automated tribotechnical complex for evaluation of lubrication processes in friction pairs / O. O. Mikosianchik, O. I. Zaporozhets, R. G. Mnatsakanov // Problems of tribology. - 2015. - № 4 (78). - P. 42-48.

34. Friction, wear and lubrication: a reference book. In 2 books. Book. 1 / ed. I.V. Kragelsky, V.V. Alisin. - Moscow: Mechanical Engineering, 1978. - P. 400.

35. Voronin $S$. $V$. The research of tribological characteristics of smectic layer of boundary film / S.V. Voronin, V.O. Stefanov // Problems of tribology. - 2014. - № 2 (72). - P. 58-64.

36. Yanzhong $W$. Wet Friction-Elements Boundary Friction Mechanism and Friction Coefficient Prediction /

W. Yanzhong, W. Bin, W Xiangyu // Tribology in Industry. - 2012. - Vol. 34. - № 4. - P. 198-205.

37. Gurskii B.E. Thermal problem of friction and its development. Part 2. The role of thermal phenomena in the destruction of gears of cylindrical involute gears of real dimensions / B. E. Gursky, A. V. Chichinadze // Friction and wear. - 2007. - No. 4 (28). - P. 418-425.

38. Klamann D.K. Lubricants and related products / D.K. Klamann. - Moscow: Chemistry, 1988. - P. 488.

39. Akhmatov A.S. Molecular physics of boundary friction / A.S. Akhmatov. - Moscow: Fizmatgiz, 1967. - P. 472.

40. Robbins M. O. Critical velocity of stick-slip motion / M. O. Robbins, P. A. Thompson // Science. -1991. - Vol. 253. - № 5022. - P. 916.

41. Thompson P. A. Origin of stick-slip motion in boundary lubrication / P. A. Thompson, M. O. Robbins // Science. - 1990. - Vol. 250 (4982). - P. 792-794.

42. Lemaitre A. Boundary lubrication with a glassy interface / A. Lemaître, J. Carlson // Physical Review. - 2004. - E 69. - P. 061611-1-061611-18.

DOI: doi.org/10.18372/38231

UDC: $541.49+546.562$

\title{
2.2 FORMATION OF COPPER (II) COORDINATION COMPOUNDS UNDER THE FRICTION PROCESS AND THEIR IMPACT ON THE TRIBOTECHNICAL CHARACTERISTICS OF THE LUBRICATING COMPOSITIONS
}

\author{
Anatoliy Ranskiy ${ }^{1}$, Olga Gordienko ${ }^{1}$, Taras Titov ${ }^{1}$, Natalia Didenko $^{2}$
}

If we take into considerationthe friction as a fundamental matter property, characterized by the energy transfer of physical bodies in contact, gravitational, electromagnetic and nuclear fields, then, for example, physicists point of view concerning friction, only as a complex physicomechanical process of contacting bodies, is quite simplified. Therefore, for today, there are no definite friction laws and, as a sequence, it is revealed the difficulty of the complete physical concept representation of the frictional forces origin, as well as their quantitative evaluation and determination of all forces dependent factors. In fact, when friction forces are taken into consideration, mainly, laws of the qualitative origin are used and represented only by some approximations, which are related to actual laws, for example, the law of Amonton (1699) and the more definite law of Coulon's experimental studies (1781). According to these facts, it is logical to consider tribology (P. Jost, 1966) as an applied science of the friction, wear, lubrication and interaction of contacting friction pairs, which is based on a vast array of practical physicochemical, mechanical, material science, technological and design studies. In this context, tribochemistry should be considered as a tribology component, which studies the chemical and physico-chemical solid surfaces transformations under the friction process, which are sequentially activated by the mechanical friction energy. 
Nowadays, 20-25\% of the world's produced energy is consumed / absorbed, under the functioning of any mechanical systems related to the friction. This leads to the formation of the important tribological tasks, which should improve the economic and environmental efficiency, durability and reliability of the machinery, mechanisms and technological equipment, which are used for various purposes. In addition, nowadays, the modern world has the fast-track developing nanotechnology related to obtaining of new materials with the unique, physico-chemical properties, micro-optoelectronic and microelectromechanical systems, which are characterized by the new friction and wear conditions, applied in the contacting microsurfaces sector [1-3]. This formed another developing tendency of tribology, specifically, nanotribology (G. Newbauer, 1990), which studies bodies friction of micro- and nanoscale. Thus, in order to study the friction of the thresholding layers with the width from $0.04 \mu \mathrm{m}$ to $0.08 \mu \mathrm{m}$ (critical width) [4], in our opinion, first of all, it is necessary to take into consideration an atomic and molecular, and adhesive / chemisorption interaction of the friction surfaces, which forms the derivation of the highly structured, liquid-crystal layers, which have high, wear-resistant properties and a low friction coefficient. Thus, in this case, under the investigation of the friction and wear, first of all, it is necessary to take into account the adhesion / chemisorption, atomic and molecular transformations, which occurr on the friction surfaces, and only then, the friction pair volume properties variation. To prove this thesis, there is the discovery of the selective transfer phenomenon (Garkunov D. M., Kragelsky I. V., 1956), which is characterized by the formation of a nano-sized servo-film in the friction pair «bronze - glycerol - steel» [5-6]. This can be applied as fundamentals for considering the selective transfer phenomenon from the outlook of nanotribology, taking into account the chemisorption phenomena and chemical transformations, which occur on the surface of the contacting friction pairs. Thus, in the study [7] the authors explain the selective transfer mechanism by a series of consecutive probable triboelectrochemical mechanoactivation reactions. The authors explain the formation on the friction surface of the servovitic film by the work of macroscopic galvanic cells, in which the surface of steel can be represented as anode, and bronze - as cathode. The reaction also proceeds on the cathodic and anodic surfaces of micro-galvanic cells. In our opinion, it is given more accurate consideration of the chemical transformations in the tribochemical system «bronze - organic additive / medium - steel» from the point of view of the direct mechanically activated dissolution of the more active metal in the donor-acceptor electron transport chain (ETC) system, which is a matrix for the formation of the corresponding copper(II) coordination complexes [8]. According to this thesis, this study is carried out concerning the investigation of the possibility of the direct synthesis of copper(II) coordination complexes with thioamide ligands in the tribochemical system «bronze BrAZ 9-4 - thioamide - organic solvent oil I-20A - steel 45» and their influence on tribotechnical characteristics of the lubricating compositions.

Methods of the lubricating compositions preparation and investigation of their tribotechnical characteristics are given below.

Preparation of lubricating compositions 1-5. $3 \mathrm{ml}$ of an organic solvent (except composition 3) was added to $97 \mathrm{ml}$ of industrial oil I-20A, and the mixtures were thoroughly mixed, using a magnetic stirrer until homogenization. The mixing process, as a rule, was carried out under the room temperature.

Preparation of lubricating compositions $7-11.0 .06 \mathrm{~g}$ of thioamide $\left(\mathrm{HL}^{1}-\mathrm{HL}^{5}\right)$ was added to $99.9 \mathrm{ml}$ of industrial oil I-20A, and it was heated to $70-90{ }^{\circ} \mathrm{C}$, and mixed until dissolved. The obtained lubricating compositions were cooled and the tribotechnical investigations were carried out.

Preparation of lubricating compositions $12,15.0 .06 \mathrm{~g}$ of thioamide $\left(\mathrm{HL}^{1}-\mathrm{HL}^{5}\right)$ was added to $3 \mathrm{ml}$ of DMF, then it was mixed until the full dissolution of thioamide and added to $97 \mathrm{ml}$ of industrial oil I-20A. If it was necessary, the homogenization of the lubricating composition was 
carried out with heating to $70-90{ }^{\circ} \mathrm{C}$, then cooled and the tribotechnical investigations were performed.

Preparation of lubricating compositions $13,16.0 .06 \mathrm{~g}$ of coordination compound $\left(\mathrm{CuL}{ }_{2}-\right.$ 5

$\mathrm{CuL}_{2}^{5}$ ) was added to $3 \mathrm{ml}$ of DMF, then heated to $70{ }^{\circ} \mathrm{C}$ and stirred until the solution was homogenized. The obtained homogeneous mixture was added to $97 \mathrm{ml}$ of industrial oil I-20A that was preheated to $70-80{ }^{\circ} \mathrm{C}$. The mixture was stirred until it was completely homogenized, cooled and the tribotechnical investigations were performed.

Preparation of the lubricating compositions 14, 17 were carried out similarly to the lubricating compositions 13,16 . In this case, for example, instead of the coordination compound $\mathrm{CuL}_{2}^{1}$, a mixture of $\mathrm{HL}^{1}+\mathrm{CuL}_{2}^{1}$ in a ratio of $1: 1$ was taken.

Methodology of the investigation. The lubricating compositions were investigated using a friction machine SMC-2 (Fig. 1) with the friction pairs «shoe-roller», sliding velocity was $3.0 \mathrm{~m} / \mathrm{s}$ and friction displacement $-3 \cdot 10^{3} \mathrm{~m}$. Material of the roller was steel 45 , shoe material - bronze BrAZ 9-4. The initial roughness was from $0.30 \mu \mathrm{m}$ to $0.62 \mu \mathrm{m}$ applied for a steel sample and from $0.62 \mu \mathrm{m}$ to $0.80 \mu \mathrm{m}$ for a bronze sample [9]. The duration of testing of one composition was 40 minutes. The temperature change in the friction zone was determined by the chromel copel thermocouple and marked on the corresponding strip chart curve of the electronic potentiometer KSP-4. The frictional force was determined with the means of a strain gauge sensor. The wear of the sample was indicated by a weighting method, which was applied on the analytical balance of the second accuracy classe VLR-200 type (GOST 24104-80). The change of mass of the samples was determined:

$$
\Delta m=m_{n}-m_{k}
$$

where $m_{\mathrm{n}}$ - initial mass of the sample, $\mathrm{g} ; m_{\mathrm{K}}$ - mass of the sample at the end of the experiment, $\mathrm{g}$.

From the friction torque curve in a strip chart was taken the value of $l \mathrm{in} \mathrm{mm}$, corresponding to the deviation of the movable carriage of the KSP-4 potentiometer at the beginning and at the end of the experiment (the mode of stable selective transfer in the friction couple). With the calibration chart, it was determined the corresponding friction torque $M_{f r}$ by the $l(\mathrm{~mm})$ deviation magnitude of the potentiometer's carriage. The friction coefficient was determined by the formula:

$$
f=\frac{M_{f r}}{r \cdot N}
$$

where $M_{f r}$ - friction torque in the investigated friction pair, $\mathrm{N} \cdot \mathrm{m} ; r$ - radius of a movable roller, $\mathrm{m} ; N-$ total load in the friction pair, N.

The installation schematic diagram of the investigated tribotechnical characteristics of the lubricating compositions in a friction pair «bronze-steel» is given in Fig. 1.

Investigation of the tribotechnical system «bronze BrAZ 9-4 - organic solvent - oil I-20Asteel 45» [11]. It is known [12, 13] that in the friction pair «bronze-steel», the friction mechanical effect leads not only to the wear of its surface, but also due to the presence of complexing reagents in the oil medium, the friction mechanical effect leads to the formation of the metal-complex compounds, which are different in the composition and structure. Initially, this phenomenon was observed in the friction pair «copper alloy - steel» in glycerine, which was oxidized as a ligand, and formed the multiplex metal-complex compounds $[14,15]$. 


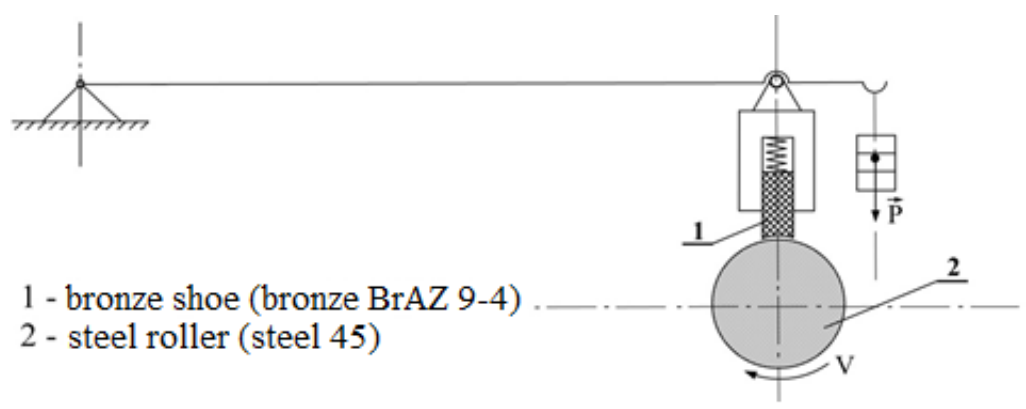

Fig. 1. The installation schematic diagram of the investigated tribotechnical characteristics of the friction pair bronze BrAZ 9-4 - steel 45, using a friction machine of SMC-2 type

The next persistent investigations of this friction pair, under the presence of $\mathrm{N}-$, Ocontaining organic ligands, were proved the formation of copper(II) coordination complexes, the presence of which, substantially improved the tribotechnical properties of the lubricating compositions $[12,16,17]$. Specifically, the wear $\left(I_{g}\right)$ and the friction coefficient $\left(f_{f r}\right)$ decrease was unambiguously associated with the oxidation of metals during the friction in the oil medium and with the formation of their coordination compounds [18].

A sufficient number of scientific surveys is devoted to the problem of the metals oxidation in the aprotic solvents. In the studies [21-23] it was frequently considered that the metals oxidative solubility, especially, the direct organometallic and coordination complexes synthesis, is determined both by the nature of the metal (the ionization potential $U$, the standard redox potential $E^{0}$, the resonant potential $I_{r}$ ), and by the nature of the organic aprotic solvent (dipole moment $\mu$, dielectric permittivity $\varepsilon^{20}$, donor number $D N_{\mathrm{SbCl}_{5}}$ ). In the researches [23-26] it is stated that metals oxidation rate $W$ depends on the donor numbers $D N_{\mathrm{SbCl}_{5}}$ of the organic solvents and has an extreme character, thus, $W=f\left(D N_{\mathrm{SbCl}_{5}}\right)$ correlation can be applied. This can be explained by the selective adsorption on the metallic surfaces, which have the diverse nature. Thus, Kuprin V. P. [27, 28] demonstrated the correlation of copper and bronze adsorption of the organic substances / solvents and their resonant potential $\left(I_{r}\right)$, which also has the similar extreme character. However, it can be assumed, that there is a direct correlation between the organic solvents donor force $\left(D N_{\mathrm{SbCl}_{5}}\right)$ and their resonant potentials $\left(I_{r}\right)$, if there is an adsorption of organic substances / solvents on the metal surface, the metals oxidation of this surface, where $\mathrm{M}^{\mathrm{n}+}$ cations are formed, and the probability of their complexation in the solution is maximum (triple conditional «resonance») then, as a consequence, the friction pair has the minimum values of the wear $\left(I_{g}\right)$ and friction coefficient $\left(f_{f r}\right)$, in the case of using such tribotechnical systems. An example of this assumption is the analysis and comparison of the different authors' investigation results, which are given in Fig. 2. The curve I represents the extreme correlation of the cadmium oxidation rate $\left(I_{r}=7.4 \mathrm{eV}\right.$ [25]) and diphenylbismuthchloride, under involving of the organic aprotic solvents, and of their donor numbers [24]. It was found that the maximum dissolution rate $\left(W_{\text {rel }}\right)$ of cadmium is observed in solvents with the highest donor activity: DMSO and DMF. The II curve shows the correlation between the obtained wear $\left(I_{g}\right)$ of the friction pair «bronze BrAZ 9-4 - steel 45» of the lubricating composition «oil I-20 A + organic solvent», and the donor numbers of the investigated organic solvents.

According to the study [27], the resonant potential is equal to $I_{r}=7.2 \mathrm{eV}$ for zero-valent copper and for its oxides $\mathrm{CuO}$ and $\mathrm{Cu}_{2} \mathrm{O} I_{r}=7.9 \mathrm{eV}$, and for bronze with the different composition, for example, with the tin composition, $I_{r}{ }^{1}=7.25 \mathrm{eV}$ and $I_{r}{ }^{2}=8,00 \mathrm{eV}$. If we assume that with the same donor force of the investigated organic solvents (curves I and II, Fig. 2) and approximately the same values of the resonant potentials for cadmium and copper, their dissolution rate coincides, 
and the wear in the friction pair «bronze-steel» is inversely proportional to the metals dissolution rate, then the correlation $W_{\text {rel }}=f\left(D N_{\mathrm{SbCl}_{5}}\right)$ and $I_{g}=f\left(D N_{\mathrm{SbCl}_{5}}\right)$, should be implemented, i.e., $W_{\text {rel }}=$ $1 / I_{g}$, which is proved by the given graphical data in Fig. 2 .

The results of the antiwear and antifriction properties investigation of the lubricating compositions 1-5 (Table 1) in a wide range of the contact load (Table. 2 and 3).

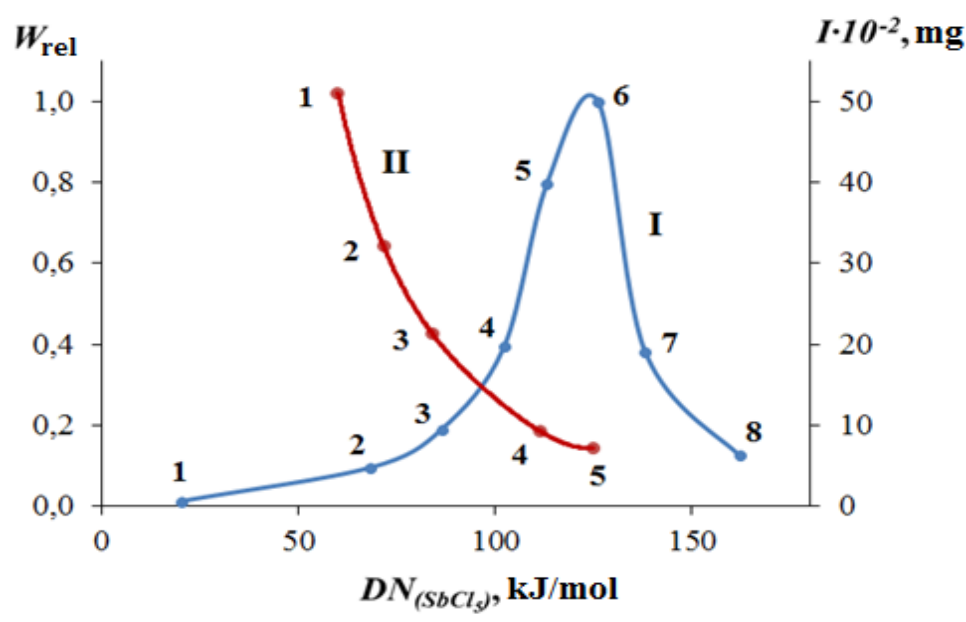

Fig. 2. The correlation of the relative dissolution rate between cadmium and bismuth diphenyl chloride and the donor numbers of the used organic solvents (I, conditions: $\left.t=20^{\circ} \mathrm{C}, \mathrm{C}_{\mathrm{ox}}=0,4 \mathrm{~mol} / \mathrm{l}\right): 1-p$-xylene; 2 - ethyl acetate; 3 - tetrahydrofuran; 4 - diglyme; 5 - DMF; 6 - DMSO; 7 - pyridine;

8 - hexamethylphosphoramideand the correlation of the wear in the friction pair «bronze BrAZ 9-4 - steel 45» with the lubricating composition «oil I-20 A + organic solvent» and donor numbers of the used organic solvents (II, conditions: $t=20^{\circ} \mathrm{C}, \tau=3 \mathrm{~h}, P=8 \mathrm{MPa}$ ): 1 - dipropyl oxalate; 2 - ethyl acetate; 3 - TCM : DMF $=1: 1 ; 4-\mathrm{DMF} ; 5$ - DMSO

Table 1

The compounds of the lubricating compositions «oil I-20A + organic solvent» and their physical, antiwear and antifriction properties

\begin{tabular}{|c|c|c|c|c|c|c|c|c|}
\hline \multirow{3}{*}{ 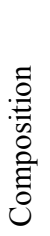 } & \multicolumn{3}{|c|}{ Compounds of the composition } & \multicolumn{3}{|c|}{ Physical properties [29] } & \multicolumn{2}{|c|}{$\begin{array}{l}\text { Tribotechnical } \\
\text { properties }\end{array}$} \\
\hline & \multicolumn{2}{|c|}{ Organic solvent } & \multirow[b]{2}{*}{$\begin{array}{c}\text { Base oil } \\
\text { I-20A }\end{array}$} & \multirow[b]{2}{*}{$\begin{array}{c}\mu, \\
\mathrm{C} \cdot \stackrel{\mathrm{m}}{\mathrm{m}} 10^{-30}\end{array}$} & \multirow[b]{2}{*}{$\varepsilon^{20}$} & \multirow[b]{2}{*}{$\begin{array}{c}D N_{\mathrm{SbCl}_{5}}, \\
\mathrm{~kJ} / \mathrm{Mol}\end{array}$} & \multirow[b]{2}{*}{$I_{g}, \mathrm{mg}$} & \multirow[b]{2}{*}{$f_{f r}$} \\
\hline & Title & $\%$ mass & & & & & & \\
\hline 1 & dipropyl oxalate & 3,0 & до 100 & - & - & 60,00 & 0,5106 & 0,32 \\
\hline 2 & ethyl acetate & 3,0 & до 100 & 6,03 & 18,51 & 71,57 & 0,3215 & 0,23 \\
\hline \multirow{2}{*}{3} & $\mathrm{TCM}$ & 1,5 & \multirow{2}{*}{ до 100} & \multirow{2}{*}{-} & \multirow{2}{*}{-} & \multirow{2}{*}{84,00} & \multirow{2}{*}{0,2128} & \multirow{2}{*}{0,19} \\
\hline & DMF & 1,5 & & & & & & \\
\hline 4 & DMF & 3,0 & до 100 & 12,70 & 36,7 & 111,33 & 0,0928 & 0,12 \\
\hline 5 & DMSO & 3,0 & до 100 & 13,03 & 48,9 & 124,73 & 0,0733 & 0,10 \\
\hline 6 & $\mathrm{I}-20 \mathrm{~A}$ & 100 & - & - & - & - & 0,6004 & 4,24 \\
\hline
\end{tabular}


Note. Investigation of the tribotechnical properties of the lubricating compositions 1-5 was carried out under the contact load of $8.0 \mathrm{MPa}$ in the friction pair «bronze BrAZ 9-4 - steel 45» under the $20^{\circ} \mathrm{C}$ temperature condition during 3 hours.

Table 2

Antiwear properties of the lubricating compositions «oil I-20A + organic solvent» under the various loads

\begin{tabular}{|c|c|c|c|c|c|c|}
\hline \multirow{2}{*}{ Composition } & \multicolumn{6}{|c|}{ Wear of the sample $I_{g}$, mg, under the contact pressure $P$, MPa } \\
\cline { 2 - 7 } & 4 & 8 & 12 & 16 & 20 & 24 \\
\hline 1 & 0,4134 & 0,5106 & 0,5747 & 0,6933 & 0,8892 & - \\
\hline 2 & 0,2200 & 0,2856 & 0,3805 & 0,4301 & 0,5408 & 0,6647 \\
\hline 3 & 0,1402 & 0,2008 & 0,2567 & 0,3200 & 0,4001 & 0,5066 \\
\hline 4 & 0,0433 & 0,0928 & 0,1867 & 0,2534 & 0,3332 & 0,4607 \\
\hline 5 & 0,0267 & 0,0733 & 0,1005 & 0,1800 & 0,2267 & 0,2940 \\
\hline 6 & 0,6003 & 0,6004 & 0,7406 & 0,9002 & - & - \\
\hline
\end{tabular}

Table 3

Antifriction properties of the lubricating compositions «oil I-20A + organic solvent» under the various loads

\begin{tabular}{|c|c|c|c|c|c|c|}
\hline \multirow{2}{*}{ Composition } & \multicolumn{6}{|c|}{ The friction coefficient $f_{f r}$ under the contact pressure $P, \mathrm{MPa}$} \\
\cline { 2 - 7 } & 4 & 8 & 12 & 16 & 20 & 24 \\
\hline 1 & 0,41 & 0,32 & 0,33 & 0,51 & 0,96 & 1,41 \\
\hline 2 & 0,37 & 0,23 & 0,19 & 0,27 & 0,48 & 0,80 \\
\hline 3 & 0,34 & 0,19 & 0,15 & 0,21 & 0,40 & 0,63 \\
\hline 4 & 0,29 & 0,12 & 0,06 & 0,08 & 0,19 & 0,41 \\
\hline 5 & 0,27 & 0,10 & 0,03 & 0,05 & 0,15 & 0,32 \\
\hline 6 & 3,76 & 4,24 & 4,85 & 5,20 & 5,15 & 5,64 \\
\hline
\end{tabular}

The results of the investigation (Table 2, 3) are represented graphically in Fig. 3.The data shown in Fig. $3 a$ represent that in the range of contact load from $4 \mathrm{MPa}$ to $24 \mathrm{MPa}$, the lubricating compositions, which contain organic solvents with high value of donor numbers $D N_{\mathrm{SbCl}_{5}}$ (compositions 4 and 5), have the best antiwear properties in the friction pair «bronze BrAZ 9-4 steel $45 »$, which unequivocally indicates the determining donor activity character of the organic aprotic solvents under the oxidation of metals. The determining influence on the wear decrease of the donor activity of organic solvents in the compounds of the lubricating compositions remains unchanged irrespectively to the contact load (4-24 MPa) in the investigated friction pair. It should be noted that the additional DMF dilution with $50 \%$ of tetrachloromethane $\left(D N_{\mathrm{SbCl}_{5}}=0\right)$ reduces the overall value of the donor activity $\left(D N_{\mathrm{SbCl}_{5}}=84,4\right.$; the value is obtained by the graphic data interpolation (Fig. 2) and increases the wear in 1.6 times compared to «pure» DMF, which again proves the important character of the aprotic solvents and their donor activity during the metals oxidation. 


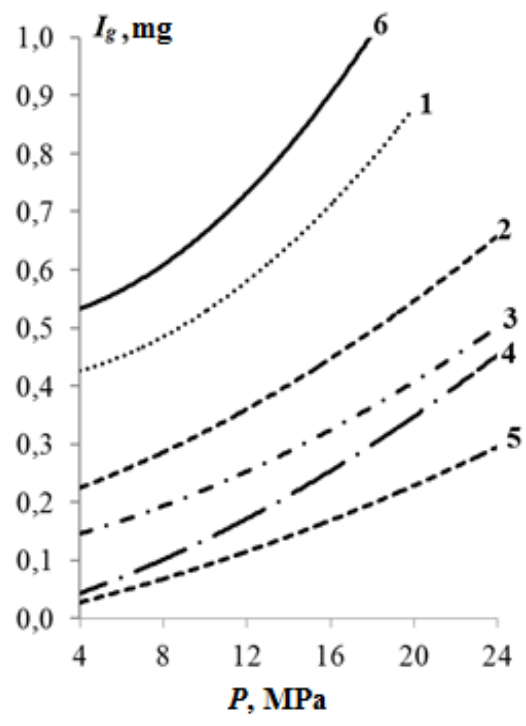

(a)

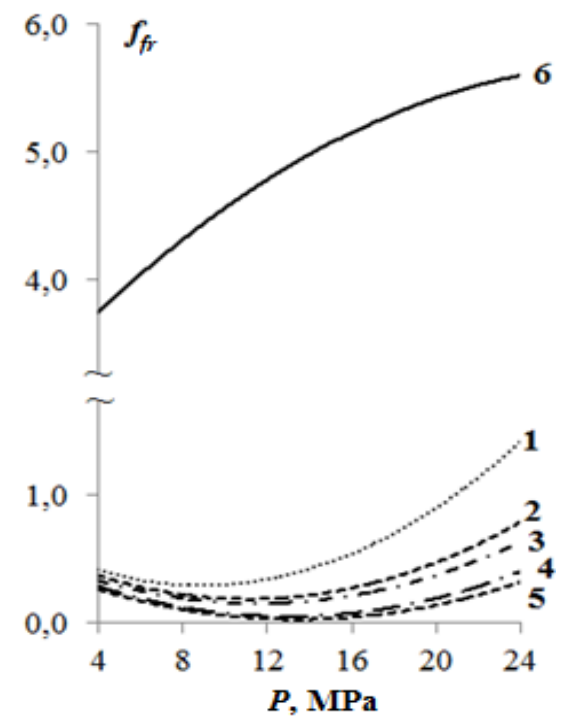

(b)

Fig. 3. The correlation between the wear $(a)$ and the friction coefficient $(b)$ under the contact load in the friction pair «bronze BrAZ 9-4 - steel 45» with the lubricating composition «oil I-20A + organic solvent» (conditions: $t=20^{\circ} \mathrm{C}, \tau=3 \mathrm{~h}$ ): 1 -dipropyl oxalate, 2 -ethyl acetate, $3-\mathrm{TCM}: \mathrm{DMF}=1: 1 ; 4-\mathrm{DMF}$; 5 - DMSO; 6 - «pure» oil I-20A

It was found out a similar correlation between the decreasing of the friction coefficient under the growth of the donor activity of the organic aprotic solvents within the pressure range from $4 \mathrm{MPa}$ to $24 \mathrm{MPa}$ for the investigated lubricating compositions (Fig. 3b). It should be considered a significantly less range of the friction coefficient change in the definite range of contact pressure. It is obviously, that it is revealed due to another mechanism of the antifriction action of the compounds of the compositions 1-5 in comparison to the mechanism of antiwear action of the same solvents.

Investigation of the tribotechnical system «bronze BrAZ 9-4 - thioamide - oil I-20 A-steel $45 »[8,30]$. In addition to the nature of aprotic solvents (Solv), the metals dissolution rate is greatly influenced by the presence of a complexing agent in the investigated systems:

$$
M^{0}+m \cdot L \cdot \frac{+O x,(+S o l v)}{-n \bar{e}} L_{m} M^{n+}+\operatorname{Re} d+P
$$

where $M^{0}$ - zero-valent metal; $L$ - complexing agent; $O \mathrm{x}$ - oxidant; $L_{\mathrm{m}} M^{\mathrm{n}+}-$ formed coordination complex; Re $d$ - reduced oxidant form; $P$ - by-products of the chemical interaction.

In our case, different substituted thioamides have been investigated as complexing agents. The thioamides, as additives to industrial oils, have been studied in detail in the following surveys $[19,31-36]$, however, the improvement of the tribotechnical properties of the friction pair «bronzesteel» was previously related only to the implementation of copper (II) selective transfer from the bronze surface to the steel surface without taking into consideration the character of the organic solvents in this process. In the studies $[9,19]$ there were investigated the lubricating compositions, which are based on the industrial oil I-20A, complexes of the mixed ligand thioamides and DMF, as an aprotic solvent. However, DMF was used to homogenize the lubricating composition and to 
improve the copper(II) metal-chelates dissolution, and not as an active component of additional dissolution of zero-valent copper in the friction pair «bronze - steel». In the context of these studies tasks, which are related to the direct synthesis of copper(II) thioamide complexes, we conducted an additional investigation of the effect of the aprotic solvents on the tribotechnical properties of the industrial oil I-20A. At first, for this purpose, the system «bronze BrAZ 9-4 - thioamide - oil I-20 A - steel 45» was investigated. In this case, the obtained data (Table. 4) and their corresponding graphical correlation is represented in Fig. 4. The investigated thioamides $\mathrm{HL}^{1}-\mathrm{HL}^{5}$, containing benzothiazole and amine -NRR' fragments, as additives to the oil I-20A, in various ways influence on the antiwear properties of the investigated lubricating compositions $7-11$. We have determined that the obtained data in the range of the 8-16 MPa contact pressure are the most important and informative.

Table 4

Compounds of the lubricating compositions «oil I-20 A + thioamide» and their antiwear and antifriction properties

\begin{tabular}{|c|c|c|c|c|c|c|c|c|c|c|c|c|c|c|c|c|}
\hline \multirow{3}{*}{ 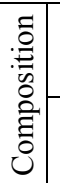 } & & & \multirow{3}{*}{$\begin{array}{l}\text { NRR' } \\
\text { S } \\
\text { design } \\
\text { ation }\end{array}$} & \multicolumn{3}{|c|}{$\begin{array}{l}\text { Compounds of the } \\
\text { composition, } \%\end{array}$} & \multicolumn{5}{|c|}{ Wear of the sample $I_{g} \cdot 10^{-1}, \mathrm{mg}$} & \multicolumn{5}{|c|}{$\begin{array}{l}\text { Friction coefficient } \\
f_{f r} \cdot 10^{-2}\end{array}$} \\
\hline & & & & \multirow{2}{*}{$\begin{array}{c}\text { thioam } \\
\text { ide }\end{array}$} & \multirow{2}{*}{ DMF } & \multirow{2}{*}{$\begin{array}{l}\text { oil I- } \\
20 \mathrm{~A}\end{array}$} & \multicolumn{10}{|c|}{ contact pressure $P, \mathrm{MPa}$} \\
\hline & & & & & & & 8 & & & & 24 & 8 & 12 & 16 & & 24 \\
\hline 7 & $\mathrm{H}$ & & $\mathrm{HL}^{1}$ & & & & & & & & & & & & & \\
\hline 8 & $\mathrm{CH}_{3}$ & 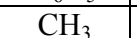 & $\mathrm{HL}^{2}$ & & & & & & & & & 5 & & & & \\
\hline 9 & & & $\mathrm{HL}^{3}$ & & & & & & & & & 0 & & & & \\
\hline 10 & $\mathrm{H}$ & & $\mathrm{HL}^{4}$ & & - & & & & & & & & & & & \\
\hline 11 & $\mathrm{H}$ & ${ }_{6} \mathrm{H}_{4} \mathrm{Br}-4$ & $\mathrm{HL}^{5}$ &, 06 & - & до 100 & 0,0 & 0,9 & 1,80 & 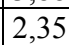 &, 00 & 5,7 & & 0,9 & & 5,5 \\
\hline
\end{tabular}

Note: $*$ - the value was obtained under the $22 \mathrm{MPa}$ contact pressure.

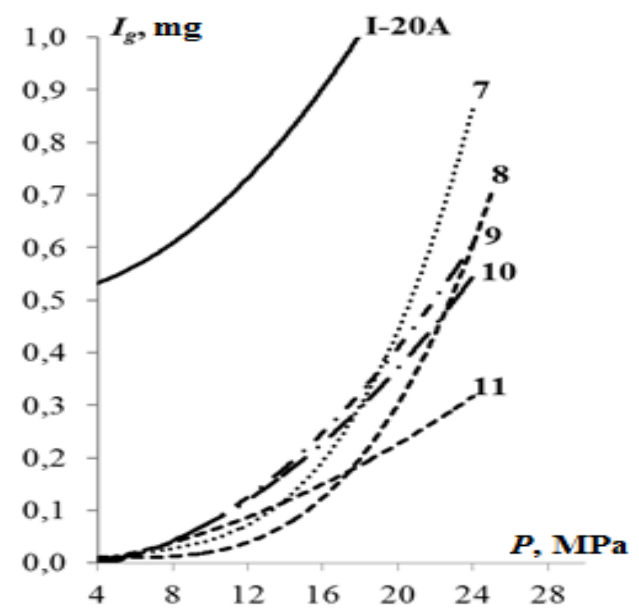

Fig. 4. The correlation between the wear and the contact pressure in the friction pair «bronze BrAZ 9-4 - steel $45 »$ with the lubricating composition «oil $\mathrm{I}-20 \mathrm{~A}+$ thioamide» $\left(t=20^{\circ} \mathrm{C}, \tau=3 \mathrm{~h}\right)$

It should be highlighted that thioamides with $N$-aryl fragment $\left(\mathrm{HL}^{1}, \mathrm{HL}^{4}, \mathrm{HL}^{5}\right)$ from $8 \mathrm{MPa}$ to $16 \mathrm{MPa}$ contact pressure range have the best results, while under the increasing of the contact pressure to $24 \mathrm{MPa}$, the antiwear activity series changes into this:

$$
\mathrm{HL}^{5}>\mathrm{HL}^{4}>\mathrm{HL}^{3}>\mathrm{HL}^{2}>\mathrm{HL}^{1},
$$


that at the first approximation can be explained by the thermicpermanence increase of the investigated heterocyclic thioamides. Thus, in the heat-resistant correlation, in the given series, $\mathrm{N}, \mathrm{N}$-dimethylamidobenzothiazole-2-thiocarboxylic acid $\left(\mathrm{HL}^{2}\right)$ is the least stable compound and is the latest in the given antiwear activity.

Fig. 5 illustrates the graphical correlation between the antifriction properties of the investigated lubricating compositions 7-11 (Table 4) and the contact load.

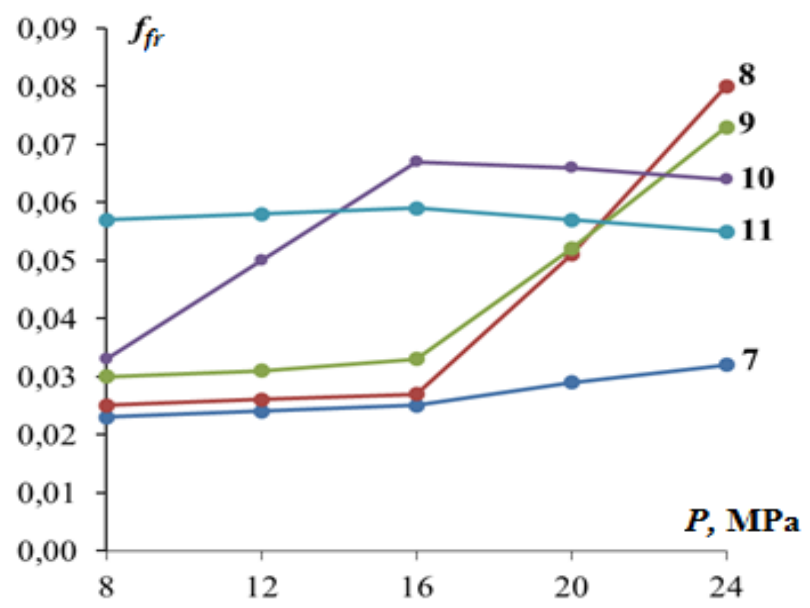

Fig. 5. The correlation between the friction coefficient and the contact pressure in the friction pair «bronze BrAZ 9-4 - steel 45» with the lubricating composition «oil I-20A + thioamide» $\left(t=20^{\circ} \mathrm{C}, \tau=3 \mathrm{~h}\right)$

It should be taken into consideration that on the correlation curves $f_{f r}-P$ the investigated lubricating compositions have a «critical» inflection point, which is equal to $16 \mathrm{MPa}$. Under the growth of contact load, for all compositions 7-11 the friction coefficient linearly increases up to $16 \mathrm{MPa}$. A further contact pressure growth leads to the linear increase of the friction coefficients only for compositions 7-9, whereas for compositions 10 and 11 the friction coefficient unexpectedly decreases. In the composition of the investigated thioamides, which revealed such properties, there were contained the chlorine atom $\left(\mathrm{HL}^{4}\right)$ and bromine atom $\left(\mathrm{HL}^{5}\right)$ in the $N$-aryl fragment, that explains such an anomalous correlation.

A comparison of the obtained antiwear and antifriction properties (Table 4) of the lubricating compositions shows that in some cases the tribotechnical properties improvement does not occur simultaneously, and it can be interpreted by the means of different mechanisms of additives action in the investigated friction pair «bronze - steel».

Investigation of the tribotechnical systems «bronze BrAZ 9-4 - oil I-20A - thioamide - DMF - steel 45» and «bronze BrAZ 9-4 - oil I-20A - Cu(II) chelate - DMF - steel 45». Previous, simpler tribotechnical systems studies revealed the organic aprotic solvents effect on the direct dissolution of zero-valent copper, which is contained in bronze BrAZ 9-4, and impact on the improvement of the antiwear and antifriction properties of the lubricating compositions, based on industrial oils. During the investigation of the same friction pair and aprotic solvent replacement with heterocyclic thioamides of the different substitutions, which included the benzothiazole fragment, their high efficiency was demonstrated, concerning the improvement of the antiwear and antifriction properties of the «bronze - steel» friction pair. According to Kuzharov A. S. [12] and our previous studies, this can be explained due to the fact, that in the friction process, coordination complexes of general formula $\mathrm{CuL}_{2}$ are formed. At the same time oxygen is the oxidant, and zerovalent copper is the reductant, which is contained in bronze: 
$(\mathrm{BrAZ} 9-4) \mathrm{Cu}^{0}+\underset{\mathrm{S}}{\longrightarrow} \mathrm{CuL}_{\mathrm{S}}+\mathrm{H}_{2} \mathrm{O}$

However, the composition of the previously studied tribotechnical system «bronze BRAZ 9-4 thioamide - oil I-20A - steel 45» (tables 4 and Fig. 4, 5) did not include organic aprotic solvents with high donor activity, for instance, DMF $\left(D N_{\mathrm{SbCl}_{5}}=111.33 \mathrm{~kJ} \cdot \mathrm{mol}^{-1}\right)$, which significantly increase the metallic copper dissolution rate, and the formation of $\mathrm{CuL}_{2}$ metal chelates, and, accordingly, improve the tribotechnical properties.

In order to eliminate this disadvantage, we conducted investigations of such tribotechnical systems:

- «bronze BrAZ 9-4 - oil I-20A - thioamide $\left(\mathrm{HL}^{1}, \mathrm{HL}^{5}\right)$ - DMF - steel 45». It was assumed that a comparison of the obtained results concerning the antiwear properties of the lubricating compositions, which contain active additives $\left(\mathrm{HL}^{1}, \mathrm{HL}^{5}\right),\left(\mathrm{HL}^{1}+\mathrm{DMF}\right)$ and $\left(\mathrm{HL}^{5}+\right.$ DMF), would reveal the character of the aprotic DMF solvent, as an active component of the tribotechnical system (additional factor), with the direct copper dissolution in the friction process;

- «bronze BrAZ 9-4 - oil I-20A - chelate $\left(\mathrm{CuL}_{2}^{1}, \mathrm{CuL}_{2}^{5}\right)$ - DMF - steel 45». It was assumed that in the case of similar results, concerning the antiwear properties, obtained by the investigation of the given systems: $\left(\mathrm{HL}^{1}+\mathrm{DMF}\right)$ and $\left(\mathrm{CuL}_{2}^{1}+\mathrm{DMF}\right),\left(\mathrm{HL}^{5}+\mathrm{DMF}\right)$ and $\left(\mathrm{CuL}_{2}\right.$ $+\mathrm{DMF})$, it is possible not only indirectly to prove the formation of metal chelates $\mathrm{CuL}_{2}^{1}, \mathrm{CuL}_{2}^{5}$, but also to reveal the active character of the aprotic solvents, because such investigations have not been carried out previously.

The results, obtained under the investigation of these systems are given in Table 5.

Table 5

Compounds of the lubricating compositions «I-20A oil + thioamide + DMF» and «I-20A oil + chelate Cu(II) + $\mathrm{DMF} »$ and their antiwear properties

\begin{tabular}{|c|c|c|c|c|c|c|c|c|c|}
\hline 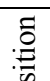 & \multicolumn{4}{|c|}{ The compounds of the composition, $\%$} & \multicolumn{5}{|c|}{$\begin{array}{c}\text { Wear } I_{g}, \mathrm{mg} \text {, under the contact pressure } \\
P, \mathrm{MPa}\end{array}$} \\
\hline ठ̊. & $\begin{array}{c}\text { thioamide } \\
\text { HL }\end{array}$ & $\begin{array}{l}\text { complex } \\
\mathrm{CuL}_{2}^{\mathbf{n}}\end{array}$ & DMF & $\mathrm{I}-20 \mathrm{~A}$ & 8 & 12 & 16 & 20 & 24 \\
\hline 7 & $\mathrm{HL}^{1}, 0,06$ & - & - & до 100 & 0,043 & 0,088 & 0,133 & 0,495 & 0,850 \\
\hline 12 & $\mathrm{HL}^{1}, 0,06$ & - & 3,0 & до 100 & 0,040 & 0,027 & 0,030 & 0,038 & 0,039 \\
\hline 13 & - & $\mathrm{CuL}_{2}^{1}, 0,06$ & 3,0 & до 100 & 0,010 & 0,014 & 0,018 & 0,027 & 0,013 \\
\hline 14 & $\mathrm{HL}^{1}, 0,03$ & $\mathrm{CuL}_{2}^{1}, 0,03$ & 3,0 & до 100 & 0,024 & 0,034 & 0,026 & 0,041 & 0,034 \\
\hline 11 & $\mathrm{HL}^{5}, 0,06$ & - & - & до 100 & 0,000 & 0,093 & 0,180 & 0,235 & 0,300 \\
\hline 15 & $\mathrm{HL}^{5}, 0,06$ & - & 3,0 & до 100 & 0,035 & 0,022 & 0,011 & 0,032 & 0,030 \\
\hline 16 & - & $\mathrm{CuL}{ }_{2}^{5}, 0,06$ & 3,0 & до 100 & 0,000 & 0,011 & 0,016 & 0,025 & 0,021 \\
\hline 17 & $\mathrm{HL}^{5}, 0,03$ & $\mathrm{CuL} \underset{2}{2}, 0,03$ & 3,0 & до 100 & 0,000 & 0,019 & 0,034 & 0,040 & 0,033 \\
\hline
\end{tabular}


In the friction pair «bronze BrAZ 9-4 - steel 45» of the lubricating compositions $12-17$, the results of the investigation regarding the wear and contact load correlation (Table 5) and represented in Fig. 6 and 7, and can be formulated as following:

- under the condition of the contact load change, in the investigated lubricating compositions, in the friction pair «bronze BrAZ 9-4 - steel 45», the wear magnitude variation is represented as a constrained values range $I_{g}$ : for the lubricating compositions 12-14 (Fig. 6) the magnitude variation is $0.013-0.041 \mathrm{mg}$, and for compositions 15-17 (Fig. 7) the magnitude variation is $0.011-0.04 \mathrm{mg}$;

- in the friction pair «bronze BrAZ 9-4 - steel 45», given intervals of the wear magnitude variation are practically identical, thus, as a sequence, we obtained the same antiwear effect mechanism of the investigated additives and lubricating compositions (Table 5);

- similar $I_{g}$ values of the investigated compositions $12-17$, for example, under the condition when $\mathrm{P}=16 \mathrm{MPa}$ demonstrate, that the active substances, which provide the antiwear properties of the investigated friction pair, are absolutely $\mathrm{CuL}_{2}^{1}$ and $\mathrm{CuL}_{2}^{5}$ coordination compounds, which are present in the I-20A industrial oil;

- the difference in $I_{g}$ values is 4.4 times for compositions $7\left(\mathrm{HL}^{1}\right)$ and $12\left(\mathrm{HL}^{1}+\mathrm{DMF}\right)$ (Table. 5, Fig. 6), for instance, under the condition when $P_{c}=16 \mathrm{MPa}$, and for compositions $11\left(\mathrm{HL}^{5}\right)$ and $15\left(\mathrm{HL}^{5}+\mathrm{DMF}\right)$, Table. 5, Fig. 7, under the same contact pressure, the difference in $I_{g}$ values is 16.4 times, and it can be considered as a very significant aprotic DMF solvent effect regarding the process of zero-valent copper dissolution according to the previously given scheme (4)

It was demonstrated the series of the antiwear and antifriction action of the investigated organic solvents under the $\mathrm{P}=8 \mathrm{MPa}$ contact load.

\begin{tabular}{|c|c|c|c|c|c|c|c|c|c|}
\hline$f_{f r}$ & $\mathrm{DMSO}$ & $>$ & $\mathrm{DMF}$ & $>$ & $\left(\mathrm{DMF}+\mathrm{CCl}_{4}\right)$ & $>$ & $\mathrm{CH}_{3} \mathrm{C}(=\mathrm{O}) \mathrm{OC}_{2} \mathrm{H}_{5}$ & $>$ & $\left(\mathrm{C}(=\mathrm{O}) \mathrm{OC}_{3} \mathrm{H}_{7}\right)_{2}$ \\
\hline$I_{g}, \mathrm{mg}$ & $\mathrm{DMSO}$ & $>$ & $\mathrm{DMF}$ & $>$ & $\left(\mathrm{DMF}+\mathrm{CCl}_{4}\right)$ & $>$ & $\mathrm{CH}_{3} \mathrm{C}(=\mathrm{O}) \mathrm{OC}_{2} \mathrm{H}_{5}$ & $>$ & $\left(\mathrm{C}(=\mathrm{O}) \mathrm{OC}_{3} \mathrm{H}_{7}\right)_{2}$ \\
\hline $\begin{array}{c}D N_{\mathrm{SbCl}_{5}} \\
\mathrm{~kJ} / \mathrm{mol}\end{array}$ & 124,73 & & 111,33 & & 84,00 & & 71,57 & & 60,00 \\
\hline
\end{tabular}

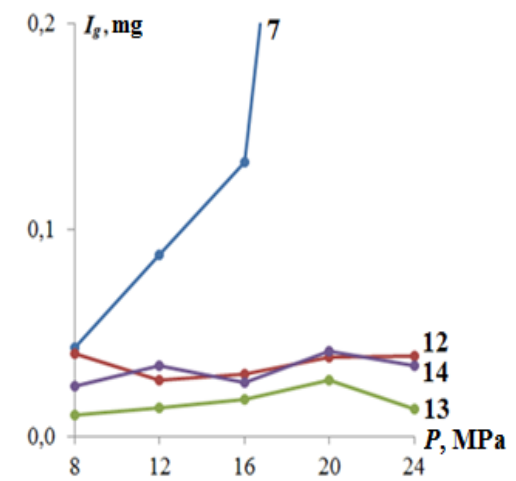

Fig. 6. The correlation between the wear and contact load in the friction pair «bronze BrAZ 9-4 - steel 45» with the lubricating compositions «oil I-20A + thioamide $\mathrm{HL}^{1}+\mathrm{DMF} »$ and «oil I-20A + chelate $\mathrm{CuL}_{2}^{1}$ » $\left(t=20{ }^{\circ} \mathrm{C}, \tau=3 \mathrm{~h}\right)$

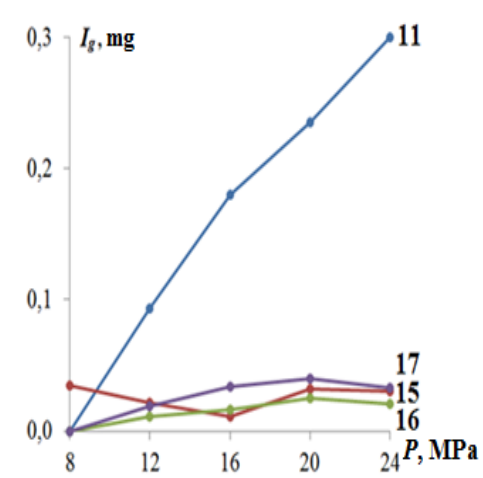

Fig. 7. The correlation between the wear and contact load in the friction pair «bronze BrAZ 9-4 - steel 45» with the lubricating compositions «oil I-20A + thioamide $\mathrm{HL}^{5}+\mathrm{DMF}$ » and «oil $\mathrm{I}-20 \mathrm{~A}+$ chelate

$$
\mathrm{CuL}_{2}^{5} \gg\left(t=20^{\circ} \mathrm{C}, \tau=3 \mathrm{~h}\right)
$$


These data specify a linear correlation of the $I_{g}$ and $f_{f r}$ decrease in relation to the increasing of the donor activity of the investigated aprotic solvents $\left(D N_{\mathrm{SbCl}_{5}}\right)$ and their ability to, additionally, increase the dissolution of zero-valent copper in the friction pair «bronze - steel» with the formation of the corresponding coordination compounds. It was found that the serial complication of the lubricating compositions $1-5,7-17$ by the addition of the organic solvents, thioamide complexones $\left(\mathrm{HL}^{1}-\mathrm{HL}^{5}\right)$, copper(II) metal chelates, based on them $\left(\mathrm{CuL}_{2}^{1}, \mathrm{CuL}_{2}^{5}\right)$, to oil I-20A allowed not only to find out a number of antiwear activity of additives, for example, for the aprotic solvent DMF:

\begin{tabular}{|c|c|c|c|c|c|c|c|c|c|}
\hline $\begin{array}{l}\text { Additives to } \\
\text { the oil I-20A }\end{array}$ & $\mathrm{I}-20 \mathrm{~A}$ & $>$ & $\mathrm{DMF}$ & $>$ & $\mathrm{HL}^{1}$ & $>$ & $\mathrm{HL}^{1}+\mathrm{DMF}$ & $>$ & $\mathrm{CuL}_{2}^{1}+\mathrm{DMF}$ \\
\hline$I_{g}, \mathrm{mg}$ & 0,6004 & & 0,0928 & & 0,0430 & & 0,0400 & & 0,0100 \\
\hline
\end{tabular}

but also to investigate the influence of each of the factors on the tribotechnical characteristics in the friction pair «bronze BrAZ 9-4 - steel 45».

Thus, the conducted investigations allow us to draw the following conclusions:

1. Organic solvents, whch are included in the lubricating compositions «oil I-20A + organic solvent» in 1,2-8,2 and 13,3-42,4 times improve, respectively, the antiwear and antifriction properties of the friction pair «bronze BrAZ 9-4 - steel 45» in comparison with «pure» oil I-20A.

2. Antiwear properties of the lubricating compositions «oil I-20A + organic solvent» in the friction pair «bronze BrAZ 9-4 - steel 45 » are determined by the donor activity $\left(D N_{\mathrm{SbCl}_{5}}\right)$ of the organic solvents: $I_{g}=f\left(D N_{\mathrm{SbCl}_{5}}\right)$. The minimum wear values are observed during there were used organic solvents (DMF, DMSO), which have the maximum values of $D N_{\mathrm{SbCl}_{5}}$.

3. The injection of the organic solvent (DMF) into the lubricating composition «oil I-20A + thioamide $\mathrm{HL}^{1}$ » provides the wear decrease in the «bronze BrAZ 9-4 - steel 45» friction pair in 4.4 times, under the contact pressure of $16 \mathrm{MPa}$. Thus, the organic solvent (DMF) is an active dissolution zero-valent copper component, which is contained in bronze.

4. Similar values of the wear in the friction pair «bronze BRAZ 9-4 - steel 45», within the presence of the lubricating compositions «oil I-20A + thioamide $\mathrm{HL}^{1}+\mathrm{DMF}$, «oil I-20A + chelate $\mathrm{CuL}_{2}^{1}+\mathrm{DMF} »$, «oil I-20A + thioamide $\mathrm{HL}^{1}+$ chelate $\mathrm{CuL}_{2}{ }_{2}+\mathrm{DMF}$ » (according to 0.030, 0.018 and $0.026 \mathrm{mg}$ under the contact pressure of $16 \mathrm{MPa}$ ) prove that in all cases the active antiwear additive to oil I-20A is the coordination compound $\mathrm{CuL}_{2}{ }_{2}$.

5. Coordination compounds of the general formula $\mathrm{CuL}_{2}$ are the effective antiwear and antifriction additives to industrial oils and can be recommended for industrial use and can be applied for the general friction pairs «bronze - steel».

\footnotetext{
РЕФЕРАТ

Анатолій Ранський, Ольга Гордієнко ${ }^{1}$, Тарас Тітов ${ }^{1}$, Наталія Діденко ${ }^{2}$

${ }^{l}$ Вінницький начіональний технічний університет,

${ }^{2}$ Вінницький наџіональний медичний університет ім. M.I. Пирогова, ranskiy@gmail.com

ФОРМУВАННЯ КООРДИНАЦЙНИХ СПОЛУК МІДІ (II) ПІД ЧАС ПРОЦЕСУ ТЕРТЯ

ТА ЇХ ВПЛИВ НА ТРИБОТЕХНІЧНІ ХАРАКТЕРИСТИКИ ЗМАЩУВАЛЬНИХ РЕЧОВИН

Досліджено трибохімічну систему «бронза БрАЖ 9-4 - органічний додаток - олива I-20A сталь 45», у якій під дією механічного активування металевих поверхонь пари тертя та органічних
} 
додатків утворюються координаційні сполуки купруму (II), що забезпечують високі протизношувальні й антифрикційні властивості мастильних композицій. Послідовне ускладнення мастильних композицій шляхом додавання до базової оливи I-20A органічних розчинників, тіоамідних лігандів та металхелатів купруму (II) на їх основі дозволило встановити ряд протизношувальної активності додатків до індустріальної оливи I-20А та дослідити вплив кожного із чинників на триботехнічні характеристики в парі тертя «бронза БрАЖ 9-4 - сталь 45». На основі отриманих результатів зроблено висновок, що покращення експлуатаційних характеристик мастильних композицій визначається утворенням у процесі трибохімічних реакцій координаційних сполук купруму (II).

Ключові слова: трибохімія, мастильні композиції, координаційні сполуки купруму(II), протизношувавльні і антифрикційні властивості

\section{PЕФЕРАТ \\ Анатолий Ранский', Ольга Гордиенко ${ }^{1}$, Тарас Титов ${ }^{1}$, Наталья Диденко $^{2}$ \\ ${ }^{1}$ Винницкий национальный технической университет, \\ ${ }^{2}$ Винницзкий национальный медицинский университет им. M.И. Пирогова, ranskiy@gmail.com \\ ФОРМИРОВАНИЕ КООРДИНАЦИОННЫХ СОЕДИНЕНИЙ МЕДИ (II) ВО ВРЕМЯ ПРОЦЕССА ТРЕНИЯ И ИХ ВЛИЯНИЕ НА ТРИБОТЕХНИЧЕСКИЕ ХАРАКТЕРИСТИКИ СМАЗЫВАЮЩИХ ВЕЩЕСТВ}

Исследована трибохимическая система «бронза БрАЖ 9-4 - органическая присадка - масло И$20 \mathrm{~A}$ - сталь 45», в которой под действием механического активирования металлических поверхностей пары трения и органических присадок образуются координационные соединения меди(II), обеспечивающие высокие противоизносные и антифрикционные свойства смазочных композиций. Последовательное усложнение смазочных композиций путем добавления к базовому маслу И-20А органических растворителей, тиоамидных лигандов и металл-хелатов меди (II) на их основе позволило установить ряд противоизносной активности присадок к индустриальному маслу И-20А и исследовать влияние каждого из факторов на триботехнические характеристики в паре трения «бронза БрАЖ 9-4 сталь 45». На основании полученных результатов сделан вывод, что улучшение эксплуатационных характеристик смазочных композиций определяется образованием в процессе трибохимических реакций координационных соединений меди(II).

Ключевые слова: трибохимия, смазочные композиции, координационные соединения меди (II), противоизносные и антифрикционные свойства

\section{ABSTRACT \\ Anatoliy Ranskiy ${ }^{I}$, Olga Gordienko ${ }^{1}$, Taras Titov ${ }^{I}$, Natalia Didenko ${ }^{2}$ \\ ${ }^{1}$ Vinnytsia National Technical University, \\ ${ }^{2}$ National Pirogov Memorial Medical University, ranskiy@gmail.com \\ FORMATION OF COPPER (II) COORDINATION COMPOUNDS UNDER THE FRICTION PROCESS AND THEIR IMPACT ON THE TRIBOTECHNICAL CHARACTERISTICS OF THE LUBRICATING COMPOSITIONS}

It has been investigated the tribochemical system «bronze BrAZ 9-4 - organic additive - oil I-20A steel 45» in which due to mechanical activation of metal particles of the surfaces of friction pair the copper(II) coordination compounds have been created. These complexes provide high antiwear and antifriction properties of the lubricating compositions. The sequential complication of lubricating compositions by adding organic solvents, thioamide ligands and metal chelates of copper(II) based on them to base oil I-20A allowed to establish an order of anti-wear activity of additives to industrial I-20A oil and investigate the influence of each of the factors on tribotechnical characteristics in friction pair «bronze BrAZ 9-4 - steel 45». Based on the obtained results, it is concluded that improvement of the operational characteristics of lubricating compositions is determined by the formation of copper(II) coordination compounds during the tribochemical reactions.

Key words: tribochemistry, lubricating compositions, copper (II) coordination compounds, antiwear and antifriction properties.

\section{REFERENCES}

1. Nanotribologija: nekotorye tendencii razvitija / [I. A. Bujanovskij, Z. V. Ignat'eva, M. M. Hrushhev et al.]. // Trenie i smazka v mashinah i mehanizmah. - 2008. - № 1. - P. 39-43. 
2. Nanotribologija: nekotorye tendencii razvitija. Prodolzhenie / [I.A. Bujanovskij, Z.V. Ignat'eva, M.M. Hrushhev et al.]. // Trenie i smazka v mashinah i mehanizmah. - 2008. - № 2. - P. 31-40.

3. Ivasyshin G. S. Nauchnye otkrytija v mikro- i nanotribologii / G. S. Ivasyshin // Trenie i smazka v mashinah i mehanizmah. - 2008. - № 4. - P. 24-27.

4. Bujanovskij I. A. A. S. Ahmatov: vydajushhijsja tribolog HH veka / I. A. Bujanovskij // Trenie i smazka v mashinah i mehanizmah. - 2010. - № 10. - P. 44-48.

5. Garkunov D. N. Tribotehnika (iznos i bezyznosnost') / D. N. Garkunov. - M.: MSHA, 2001. -616 p.

6. Kragel'skij I. V. Razvitie nauki o trenii. Suhoe trenie / I. V. Kragel'skij, V. S. Shhedrov. - M.: Izd-vo ANSSSR, 1956. $-236 \mathrm{p}$.

7. TriboJeDS pri trenii v rezhime bezyznosnosti / [A. S. Kuzharov, S. B. Bulgarevich, V. Je. Burlakova et al.] // Trenie i smazka v mashinah i mehanizmah. - 2009. - № 7. - P. 3-11.

8. Didenko $N$. O. Prjamyj syntez koordynacijnyh spoluk kuprumu(II) z tioamidamy riznogo zamishhennja: dys. kand. him. nauk: 02.00.01 / Didenko N. O. - Vinnycja, 2017. - 168 p.

9. Doslidzhennja polifunkcional'nyh vlastyvostej N,S-vmisnyh organichnyh spoluk ta i'h metal-helativ v industrial'nyh olyvah / [A. P. Ranskiy, O. A. Gordienko, N. O. Didenko et al.] // Materialy H mizhnarodnoi' naukovo-tehnichnoi' konferencii' «AVIA-2011». - Vol. 3. - Kyi'v : NAU, 2011. - P. 18.104-18.107.

10. Dudka A. M. Metodychni vkazivky do vykonannja laboratornyh ta praktychnyh robit $\mathrm{z}$ dyscypliny «Proektuvannja trybotehnichnyh system» dlja studentiv IV kursu special'nosti 6.090220 / A. M. Dudka, O. V. Stovpnyk, O. S. Kabat. - Dnipropetrovs'k: UDHTU, 2007. - 31 p.

11. Doslidzhennja trybohimichnoi' systemy «bronza BrAZh 9-4 - organichnyj dodatok - olyva I-20A - stal' 45» / O. A. Gordienko, T. S. Titov, A. P. Ranskiy, O. V. Dyha // Problemy trybologii'. - 2017. - № 2. - P. $43-$ 49.

12. Prjamoj sintez koordinacionnyh soedinenij / [V. V. Skopenko, A. D. Garnovskij, V. N. Kokozej et al.]. - K.: Venturi, 1997. $-172 \mathrm{p}$.

13. Ponomarenko A. G. O mehanizme obrazovanija polimerov trenija v smazochnyh maslah A. G. Ponomarenko, G. G. Chigarenko, G. P. Berchan // Trenie i iznos. - 1981. - Vol. 2. - № 9. - P. 43-45.

14. Garkunov D. N. Omehanizme vzaimnogo atomarnogo perenosa medi pri trenii bronzy po stadii / D. N. Garkunov, V. N. Lozovskij, A. A. Poljakov // Dokl. AN SSSR. - 1960. - Vol. 133. - № 5. - P. 11281129 .

15. Spravochnik po tribotehnike. Teoreticheskie osnovy / Pod red. M. Hebdy, A. V. Chichinadze. - M.: Mashinostroenie, 1989. - T. 1. -400 p.

16. Issledovanie struktury granichnogo sloja vlijanija kompleksoobrazujushhih prisadok na tribotehnicheskie svojstva pary trenija mednyj splav-stal' / [A. S. Kuzharov, V. V. Chuvaev, B. V. Merinov et al.] // Trenie i iznos. - 1987. - T. 8, № 5. - P. 851-856.

17. Barchan G. P. Issledovanie izbiratel'nogo perenosa v srede slozhnyh jefirov monokarbonovyh kislot / G. P. Barchan, G. G. Chigarenko, A. G. Ponomarenko // Himija i tehnologija topliv i masel. - 1978. - № 10. - P. 59-61.

18. Barchan G. P. Vlijanie stroenija slozhnyh jefirov na process izbiratel'nogo perenosa / G. P. Barchan, G. G. Chigarenko, A. G. Ponomarenko // Himija I tehnologija topliv i masel. - 1979. - № 7. - P. 36-39.

19. Ranskiy A. P. Doslidzhennja prysadnyh materialiv na osnovi trygalogenpohidnyh karbonovyh kyslot v olyvi Y-40 / A. P. Ranskiy, O. A. Gordienko // Problemy trybologi”. - 2012. - № 1. - P. 55-61.

20. Garnovskij A. D. Prjamoj sintez koordinacionnyh soedinenij iz metallov v nevodnyh sredah / A. D. Granovskij, Ju. I. Rjabuhin, A. S. Kuzharov // Koordinacionnaja himija. - 1984. - T. 10. - № 8. - P. 1011-1033.

21. Tehnologichnyj dyzajn prysadok do industrial'nyh olyv, otrymanyh reagentnoju pererobkoju vysokotoksychnyh promyslovyh vidhodiv / [T. S. Titov, A. P. Ranskiy, O. V. Dyha et al.] // Problemy trybologii'. - 2014. - № 4. - P. 8189.

22. Maslennikov Stanislav Vladimirovich. Okislenie metallov organicheskimi soedinenijami v aprotonnyh rastvoriteljah: dis. Dokt. Him. Nauk : 02.00.08, 02.00.04 / Maslennikov Stanislav Vladimirovich. - Nizhnij Novgorod, 2005. $-201 \mathrm{p}$.

23. Rol' rastvoritelja $\mathrm{v}$ sinteze metalloorganicheskih i metallosoderzhashhih soedinenij prjamym okisleniem metallov / S. V. Maslennikov, I. V. Spirina, A. V. Piskunov, S. N. Maslennikova // Zhurnal obshhej himii. - 2001. - T. 71. - Vyp. 11. - P. 1837-1838.

24. Vlijanie prirody rastvoritelja na skorost' okislenija metallov $\mathrm{v}$ aprotonnyh sredah / S. V. Panteleev, S. V. Maslennikov, A. N. Egorochkin, V. Ju. Vakulenko // Zhurnal obshhej himii. - 2001. - T. 77. - Vyp. 6. - P. 912-916. 
25. Korreljacija reakcionnoj sposobnosti jelementoorganicheskih hloridov $\mathrm{v}$ reakcii okislenija metallov $\mathrm{v}$ aprotonnyh sredah / S. V. Panteleev, S. V. Maslennikov, A. N. Egorochkin, I. V. Spirina // Zhurnal obshhej himii. - 2007. - T. 77. - Vyp. 7. - P. 1072-1074.

26. Kuprin V. P. Adsorbcija organicheskih soedinenij na tverdoj poverhnosti / V. P. Kuprin, A. B. Shherbakov. - Kiev: Naukova dumka, 1996. -162 p.

27. Kuprin Vitalij Pavlovich. Izbiratel'naja adsorbcija organicheskih veshhestv na metallah i podgotovka poverhnosti pered naneseniem pokrytij : dis. Dokt. Him. Nauk : 02.00.05/ Kuprin Vitalij Pavlovich. Dnepropetrovsk, 1993. -323 p.

28. Pal'm V. A. Osnovy kolichestvennoj teorii organicheskih reakcij / V. A. Pal'm. - L.: Himija, 1977. - 360 p. 29. Doslidzhennja trybohimichnoi' systemy «bronza BrAZh 9-4-tioamid-olyva I-20A - stal' 45» / [O. A. Gordienko, N. O. Didenko, T. S. Titov ta in.] // Problemy trybologii'. - 2018. - T. 88, № 2. - P. 89-93. 30. Himija tioamidov. Soobshhenie III. Sintez i issledovanie nekotoryh tioamidov kak prisadok k smazochnym materialam / A. P. Ranskiy, I. G. Ploshenko, A. G. Panasjuk, M. Ju. Vakulenko // Voprosy himii i himicheskoj tehnologii. - 2003. - № 4. - P. 150-153.

31. Himija tioamidov. Soobshhenie IV. Aril- i alkilamidy benztiazol-2-tiokarbonovoj kisloty kak prisadki k smazochnym maslam / A. P. Ranskiy, I. G. Ploshenko, A. G. Panasjuk, M. Ju. Vakulenko // Voprosy himii i himicheskoj tehnologii. - 2003. - № 6. - P. 177-181.

32. Ranskiy A. P. Himija tiamidov. Soobshhenie V. Alkil-, arilamidy benzimidazol-2-tiokarbonovoj kisloty kak prisadki k smazochnym maslam / A. P. Ranskiy, I. G. Ploshenko, A. G. Panasjuk // Voprosy himii i himicheskoj tehnologii. - 2004. - № 4. - P. 42-46.

33. Ranskiy A. P. Himija tioamidov. Soobshhenie VI. Addukty N-alkil-N-ariltio $\neg$ amidov $\mathrm{s}$ galogenkarbonovymi kislotami kak prisadki k industrial'nym maslam / A. P. Ranskiy, A. G. Panasjuk, M. V. Kuchuk // Voprosy himii i himicheskoj tehnologii. - 2005. - № 2. - P. 139-141.

34. Ranskiy A. P. Himija tioamidov. Soobshhenie VIII. Smeshannoligandnye kompleksy medi(II) arilamidov benzimidazol-2-tiokarbonovoj kisloty kak prisadki k smazochnym maslam / A. P. Ranskiy, A. G. Panasjuk // Voprosy himii i himicheskoj tehnologii. - 2005. - № 2. - P. 42-45.

35. Ranskiy A. P. Himija tioamidov. Soobshhenie H. Sintez mednyh kompleksov alkilamidov benzimidazol-2tio $\neg$ karbonovoj i galogensoderzhashhih kislot $\mathrm{i}$ ih issledovanie kak prisadok $\mathrm{k}$ smazochnym maslam / A. P. Ranskiy, A. G. Panasjuk, A. A. Mitrohin // Voprosy himii i himicheskoj tehnologii. - 2006. - № 4. - P. 36-41.

36. A. s. 1409643 A1 SSSR, MKI S07M141/08. Smazochnaja kompozicija / B. A. Bovykin, I. G. Ploshenko, A. P. Ranskiy, A. A. Mitrohin, A. Ja. Shtan'ko, S. P. Suhovoj, V. D. Sedleckij. - zajavl. 26.02.1986 ; opubl. 15.07.1988, Bjul. № 26.

DOI: doi.org/10.18372/38220

UDC: $629.063 .6-028.82(045)$

\title{
2.3 DEVELOPMENT OF ALTERNATIVE JET FUELS MODIFIED WITH CAMELINA OIL BIO-ADDITIVES
}

\author{
Anna Iakovlieva ${ }^{1}$, Sergii Boichenko ${ }^{2}$, Kazimierz Lejda ${ }^{2}$, Hubert Kuszewski ${ }^{2}$, Oksana Vovk ${ }^{1}$
}

Constant increase of aircraft fleet and exhausting crude oil deposits promote worsening of the world energy crisis. As a result we observe rise in prices for jet fuel (JF) that today comprise about $25-30 \%$ of passenger travel [1]. Moreover, products of fuel combustion cause detrimental impact on environment. Thus, the task of search and development of alternative JFs became especially important.

This work is devoted to the study of possibilities of partial replacement of conventional JFs with components of biological (plant) origin. It will allow decreasing the dependence on exhaustible energy sources and minimizing negative impact of aviation on environment.

Today alternative fuels from various renewable feedstock are actively developed and studied. Among them are fuels made of biomass, plant oils, animal fats, microalgae, waste from agriculture, wood processing industry, municipal waste etc [2]. JFs produced from biomass via FT- 